\title{
ПРОЯВ КОМБІНАЦІЙНОЇ ЗДАТНОСТІ СВИНЕЙ ІРЛАНДСЬКОЇ СЕЛЕКЦІЇ ЗА ПРОМИСЛОВОГО ВИРОБНИЦТВА СВИНИНИ В УМОВАХ СТЕПУ УКРАЇНИ
}

\author{
Оглобля Вікторія Вікторівна \\ здобувач ступеня вищої освіти «Доктор філософії» \\ Полтавська державна аграрна академія \\ ORCID: 0000-0002-4630-7222 \\ E-mail: vika.ohloblia@gmail.com
}

Повод Микола Григорович Сумський національний аграрний університет доктор сільськогосподарських наук, профессор

ORCID: 0000-0001-9272-9672 E-mail: nic.pov@ukr.net

\author{
Цап Світлана Володимирівна \\ кандидат сільськогосподарських наук, доцент \\ Дніпровський державний аграрно-економічний університет \\ ORCID: 0000-0002-2495-949X \\ E-mail: tsap.svetlana@i.ua.
}

Проведена оцінка ефеекту гетерозису за прямого та реципрокного схрещування основних материнських порід великої білої та ландрас ірландського походження в умовах промислової технології виробниитва свинини в степу України. Встановлено прояв ефректу гетерозису за більшістю материнських ознак як за прямого так і зворотного схрещування основних материнських порід. Але за різними ознаками його ефрект був неоднаковим. За багатоплідністю встановлено ефект гетерозису як при прямому так і зворотному схрещуванні. Найвищим при прямому схрещуванні виявився показник специфічного гетерозису - 8,97\%, тоді як справжній та загальний гетерозис проявились на рівні 7,48\%. За зворотного варіанту поєднання свиней цих порід загальний гетерозис за показником багатоплідності склав $3,45 \%$, справжній та специфрічний гетерозис становили 2,04\%,тоді як гіпотетичний склав 2,74\%. У свиноматок великої білої породи при поєднання їх з кнурами породи ландрас спостерігалися негативні значення всіх видів гетерозису на рівні 5,24 -5,47\%. За зворотного поєднання свиней цих порід встановлено позитивний загальний гетерозис - 3,90\%, справжній та специфрічний становили $3,65 \%$, а гіпотетичний - 3,77\%. За кількістю поросят при відлученні ефект гетерозису виявився нижчим

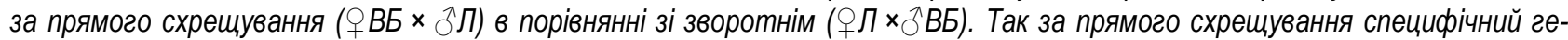
терозис склав 3,36\%, тоді як гіпотетичний 2,50\%. За зворотного схрещування тварин иих порід ефект загального гетерозису склав 7,56\%, справжнього та специрічного гетерозису 5,79\% а гіпотетичного - 6,67\%. Ефект гетерозису за масою гнізда поросят при відлучені у свиноматок породи ландрас осімененних спермою кнурів великої білої породи був наступним - загальний - 6,60\%, гіпотетичний - 6,40\%, справжній та специсрічний - 6,20\%. Ефект гібридної сили за комплексом ознак відтворювальних якостей свиноматок за показником СІВЯС найвищим був ефрект специрічного гетерозису за поєднання порід ㅇБ × $\widehat{\nearrow} Л-8,88 \%$, тоді як гіпотетичний гетерозис за СІВЯС склав 8,26\%, а загальна та справжня його форми знаходились на рівні 7,65\%. За поєднання свиноматок породи ландрас з кнурами великої білої породи ефекти гетерозису за СІВЯС загальний гетерозис за комплексом цих ознак склав для даного поєднання 2,64\%, гіпотетичний - 2,05\%, а специфічний та справжній по 1,48\%. За більшістю відтворювальних якостей свиноматок материнських генотипів великої білої та ландрас порід виявлено ефрект гетерозису як при прямому так і зворотному їх схрещуванні. При схрещуванні свиноматок великої білої породи з кнурам породи ландрас найвищим прояв ефеекту гетерозису був за загальною кількістю поросят при народжені - 1,18 .. 8,86\%, багатоплідності - 7,48 ... 8,97\% та селекційним індексом відтворювальних якостей (CІВЯС) - 7,85 - 8,88\%. За реципрокного варіанту схрещування тварин иих порід найвищим показник гетерозису виявився за кількістю поросят при відлучені - 5,79 ... 7,56\%, масою поросят при відлучені 6,20 ... 6,60\% та оціночним індексом з обмеженою кількістю ознак (IВЯ) - 3,93 ... 5,08\%.

Ключові слова: свиноматка, порода, поєднання, гетерозис, багатоплідність, схрещування, середньодобові прирости

DOI: https://doi.org/10.32845/bsnau.lvst.2020.4.9

Одним 3 основних показників рентабельності свинарства $€$ багатоплідність свиноматок. Ще в минулому сторіччі дослідженнями Д.И. Грудев [1] встановлено, що підвищення багатоплідності на одну голову понад восьми порося в гнізді веде до зниження собівартості одного поросяти після відлучення на 8-12\%. В сучасному свинарстві, як стверджують Н.А. Зиновьева з співавторами [2] розмір гнізда свиноматки залежить від породної належності вихідних батьківських форм. Як повідомляють E. Avalos та C. Smith [3] селекція на багатоплідність малоефективна, тому що дана ознака має низьку успадковуваність. Для збільшення багатоплідності на 0,8 голови, за їхніми розрахунками необхідно впродовж 16 років вести відбір на багатоплідність за 50 \% бракування маток. А відсутність спрямованого відбору за цією ознакою як стверджує Р.И. Шейко [4] призводить до зниження багатоплідності внаслідок відбору краще розвине- 
них поросят 3 невеликих гнізд. Але як стверджує Ф.В. Жирнов [5], ефеективність відтворювальної здатності свиноматок залежить не тільки від індивідуальних їх особливостей, але і від поєднуваності з кнурами певних генотипів. За даними науковців за міжпородного промислового схрещування багатоплідність підвищується на 12-16 \%.

За повідомленнями В.П. Рибалко [21], Л.П. Гришиної [19], А.А. Геті [14] найбільш простою формою схрещування в свинарстві $€$ двопородне і в їх роботах наводиться його есрективність. Як стверджують $[9,14,19,21]$ три- та багатопородне схрещування $€$ більш ефективним в порівнянні 3 двопородним, але стабілізації цього ефекту повинна враховуватись комбінативна здатність вихідних форм. Більш високою формою розведення свиней за твердженнями $A$. Анкер [20] є внутрішньопородна та породно-лінійна гібридизація, за якої ведеться роздільна селекція в материнських та батьківських лініях. Вона дозволяє за свідченнями О.М. Церенюка [9] забезпечити високу поєднувальність за низкою ознак які не корелюють одна з одною. Останнім часом як стверджує А.А. Гетя [14] для гібридизації використовують спеціалізовані материнські та батьківські форми створені як на однопороідній основі так і синтетичні створені за участі декількох порід.

Більшість світових генетичних компаній в якості материнських фрорм використовують свиней порід ландрас та великої білої. Для покращення відтворних якостей в промисловому свинарстві зазвичай використовують двопородні помісі $F_{1}$ від прямого та зворотного схрещування тварин цих порід, що дозволяє додатково використати ефект гібридної сили за відтворювальними ознаками продуктивності $[11,18]$. Враховуючи, що більшість промислових господарств використовують для виробництва свинини продукт зарубіжного походження, важливим є вивчення поєднувальної здатності тварин материнських генотипів в умовах степу України.

Актуальність та мета досліджень полягала у вивченні комбінаційної здатності основних материнських порід ірландської селекції в геокліматичних умовах степу України та визначення оптимального їх поєднання для використання в умовах індустріальних технологій.

Матеріали та методи досліджень. Для проведення вивчення комбінаційної здатності свиней великої білої та ландрас порід ірландської генетичної компанії Хермітаж Генетікс було за принципом груп аналогів відібрано чотири групи свиноматок по 60 голів в кожній (табл. 1)

Таблиця 1

Схема досліду з вивчення комбінаційної здатності свиней материнських порід

\begin{tabular}{|c|c|c|c|}
\hline \multirow{2}{*}{ Група } & \multicolumn{2}{|c|}{ Свиноматки } & \multicolumn{2}{|c|}{ порода } \\
\cline { 2 - 5 } & порода & кількість & велика біла (ВБ) \\
\hline I & велика біла (ВБ) & 60 & ландрас (Л) \\
\hline III & ландрас (Л) & 60 & ландрас (Л) \\
\hline IV & велика біла (ВБ) & 60 & велика біла (ВБ) \\
\hline
\end{tabular}

Першу та третю групи склали чистопородні свиноматки великої білої породи. До другої та четвертої групи ввійшли чистопородні їх аналоги породи ландрас тієі ж компанії. Свиноматок I та IV груп, осіменяли спермою кнурів великої білої породи ірландської селекції. Їх ровесниць з ІІ та III груп осіменяли спермою кнурів породи ландрас ірландської селекції. Утримання свиноматок в усі періоди репродуктивного циклу було ідентичним відповідно норм компанії РIC. Годівля також була ідентичною, повнораціонною та збалансованою, комбікормами власного виробництва. В період опоросу і лактації свиноматок враховували наступні показники продуктивності: загальну кількість народжених поросят, багатоплідність, масу гнізда поросят при народженні, кількість, індивідуальну масу та масу гнізда поросят при відлучені.

Комплексну оцінку відтворних якостей свиноматок визначали за допомогою оціночного індексу відтворювальних якостей, розробленого Лашем та Мольна у модифікації М.Д. Березовського та Д.В. Ломако [13]:

$$
I=B+2 W+35 G,
$$

де: В-кількість поросят при народженні, гол;

W - кількість відлучених поросят, гол.;

G - середньодобовий приріст поросят до відлучення,

Кг.

Селекційний індекс відтворювальних якостей свиноматок (СІВЯС) визначали згідно методики О.М. Церенюка [9]:

$$
\text { СІВЯС }=6 \mathrm{X}_{1}+9,34\left(\frac{\mathrm{X}_{2}}{\mathrm{X}_{3}}\right),
$$

де: СІВЯС - селекційний індекс відтворювальних якостей свиноматок;
$\mathrm{X}_{1}$-багатоплідність, гол;

$\mathrm{X}_{2}$-маса гнізда при відлученні, кг;

$\mathrm{X}_{3}$ - термін відлучення, діб; 6 та 9,34 - коефріцієнти.

Індекси гетерозису визначали за формулами, запропонованими В.Т. Горіним, І.М. Нікітченком [12] вдосконалених О.М. Церенюком [22].

$$
\Gamma c=\left(\frac{O z}{O \kappa} \times 100\right)-100,
$$

де: Гс - справжній гетерозис;

Ог - ознака гібриду;

Ок - ознака кращої батьківської форми;

$$
\Gamma 2=\left(\frac{2 \times O z}{O б+O M} \times 100\right)-100,
$$

де: Гг - гіпотетичний гетерозис;

Ог - ознака гібриду;

Об - ознака батьківської форми;

Ом - ознака материнської фрорми;

$$
\Gamma_{3}=\left(\frac{O z}{O_{M}} \times 100\right)-100,
$$

де: Гз - загальний гетерозис;

Ог - ознака гібриду;

Ом - ознака материнської форми;

$$
\Gamma c \phi=\left(\frac{O z}{O \sigma} \times 100\right)-100,
$$

де: Гсф - специфрічний гетерозис;

Ог - ознака гібриду;

Об - ознака батьківської форми.

Результати досліджень. За даними досліджень на племінному репродукторі ТОВ «НВП» Глобинський свиноко- 
мплекс» проведена оцінка ефекту гетерозису за найбільш поширеною в зоотехнічній практиці методикою В.Т. Горіна і І.М. Нікітченка.(12). Як видно з таблиць 1-3 за більшістю відтворних ознак встановлено прояв ефекту гетерозису як за прямого так і зворотного схрещування основних материнських порід. Але за різними ознаками його ефект був неоднаковим. Так за потенційною багатоплідністю ( табл. 1) справжній гетерозис на рівні $1,18 \%$ спостерігався при прямому схрещуванні свиноматок великої білої породи з кнурами породи ландрас. За цього поєднання на такому ж рівні виявився і загальний гетерозис тоді як гіпотетичний склав $4,88 \%$. Найбільшого значення за даного поєднання набрав есрект специфічного гетерозису - 8,86\%.

Ефект гетерозису за показниками відтворювальної якості свиноматок під час опоросу

\begin{tabular}{|c|c|c|c|c|c|}
\hline Поєднання порід & Показник & Гіпотетичний гетерозис, \% & Загальний гетерозис, \% & Справжній гетерозис, \% & Специфічний гетерозис, \% \\
\hline \multicolumn{6}{|c|}{ Загальна кількість народжених поросят, гол } \\
\hline कB $\mathrm{B} \times \widehat{\mathrm{O}} \mathrm{B}$ & 17 & & & & \\
\hline क्× × & 15,8 & & & & \\
\hline $9 \mathrm{~B} 5 \times \hat{O} \Omega$ & 17,2 & 4,88 & 1,18 & 1,18 & 8,86 \\
\hline 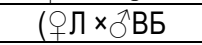 & 16,2 & $-1,22$ & 2,53 & $-4,71$ & $-4,71$ \\
\hline \multicolumn{6}{|c|}{ Багатоплідність, гол } \\
\hline $\mathrm{OBE} \times \widehat{\mathrm{B} B}$ & 14,7 & & & & \\
\hline कЛ × ठ̀ Л & 14,5 & & & & \\
\hline $9 \mathrm{BE} \times \widehat{\bigcirc} Л$ & 15,8 & 8,22 & 7,48 & 7,48 & 8,97 \\
\hline$\left({ }^{\circ} Л \times O^{\wedge} \mathrm{B} Б\right.$ & 15 & 2,74 & 3,45 & 2,04 & 2,04 \\
\hline \multicolumn{6}{|c|}{ Великоплідність, кг } \\
\hline 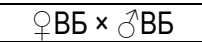 & 1,31 & & & & \\
\hline कЛ × ठЛ & 1,32 & & & & \\
\hline $9 \mathrm{~B} Б \times \widehat{O} \Omega$ & 1,29 & $-1,90$ & $-1,53$ & $-2,27$ & $-2,27$ \\
\hline 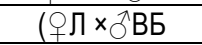 & 1,32 & 0,38 & 0,00 & 0,00 & 0,76 \\
\hline
\end{tabular}

За реципрокного варіанту схрещування встановлено тільки загальнийефект гетерозису за потенційною багатоплідністю. Решта форм гетерозису за такого поєднання була відсутня.

За багатоплідністю встановлено ефект гетерозису як при прямому так і зворотному схрещуванні тварин великої білої та ландрас порід ірландського походження. Так за поєднання маток великої білої породи та кнурів породи ландрас найвищим виявився показник специфрічного гетерозису - 8,97\%, тоді як справжній та загальний гетерозис проявились на рівні 7,48\%. Де що вищим на 0,74\% виявився гіпотетичний гетерозис.

За зворотного варіанту поєднання свиней цих порід ефект гібридної сили був суттєво нижчим. Так загальний гетерозис за показником багатоплідності в цьому поєднані склав 3,45\%. Водночас справжній та специфічний гетерозис становили 2,04\%,тоді як гіпотетичний склав 2,74\%.

Великоплідність свиноматок має негативну кореляцію з кількістю поросят при народженні. Тому в поєднанні свиней з великою кількістю поросят при народжені спостерігалось негативне значення ефекту гетерозису. За прямого схрещування тварин ( ня даної ознаки і ефрект гібридної сили був негативним від 1,53 до 2,27\%. Водночас за поєднання маток породи ландрас з кнурами великої білої породи встановлено незначний есект специфічного 0,76\% та гіпотетичного 0,38\% гетерозису за ознакою великоплідності.

На показники збереженості, кількості та маси поросят при відлученні в дещо більшій мірі впливають разом з генотиповими факторами і паратипові. Так, враховуючи найвищу багатоплідність свиноматок, та негативну кореляцію багатоплідності і збереженості поросят закономірним $є$ відсутність ефекту гетерозису за збереженістю поросят у свиноматок великої білої породи при поєднання їх з кнурами породи ландрас (табл. 2).

За цього поєднання спостерігалися негативні значення всіх видів гетерозису на рівні $5,24-5,47 \%$. Водночас за зворотного поєднання свиней цих порід встановлено позитивний гетерозис. Так найвищим значенням характеризувався загальний гетерозис - 3,90\%,тоді як справжній та специфічний становили $3,65 \%$, а гіпотетичний $-3,77 \%$.

Значно вищий прояв ефекту гібридної сили спостерігався в обох поєднаннях за кількістю поросят при відлученні. І він виявився нижчим за прямого схрещування (ВБ × $\nwarrow$ Л) в порівнянні зі зворотнім ( помісей над кращою вихідною формою (справжній гетерозис) та переважання помісей над материнською формою (загальний) становили за кількістю поросят при відлучені при схрещуванні маток великої білої породи та кнурів породи ландрас - 1,65\%. Найвищим рівнем за цією ознакою виявився специфічний гетерозис $3,36 \%$, тоді як гіпотетичний встановлено на рівні 2,50\%. За поєднання свиноматок породи ландрас з кнурами великої білої породи ефект гетерозису за кількістю поросят при відлучені був вищим у всіх його проявах. Найвищим виявився загальний гетерозис, рівень якого сягнув за цього поєднання $7,56 \%$, водночас показники справжнього та специфрічного гетерозису знаходились на рівні 5,79\%, гіпотетичний склав - 6,67\%.

За показником індивідуальної маси поросят при відлучені ефект гібридної сили був суттєво меншим за обох варіантів поєднань материнських порід. Так за поєднання маток великої білої породи з кнурами породи ландрас спостерігався досить низький загальний 0,90\% та гіпотетичний - 0,22\% гетерозис, тоді як інші його форми мали негативні показники.

За зворотного поєднання тварин цих порід значення всіх форм прояву гібридної сили були негативними, в межах 0,22-0,89\%. 
Таблиця 2

Ефект гетерозису за показниками відтворювальної здатності свиноматок при відлученні

\begin{tabular}{|c|c|c|c|c|c|}
\hline Поєднання порід & Показник & Гіпотетичний гетерозис, \% & Загальний гетерозис, \% & Справжній гетерозис, \% & Специфрічний гетерозис, \% \\
\hline \multicolumn{6}{|c|}{ Збереженість, \% } \\
\hline 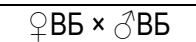 & 82,3 & & & & \\
\hline क्र× & 82,1 & & & & \\
\hline $\mathrm{OBE} \times \hat{\mathrm{O}} \Omega$ & 77,8 & $-5,35$ & $-5,47$ & $-5,47$ & $-5,24$ \\
\hline$(\Phi Л \times \bigwedge \mathrm{B} B$ & 85,3 & 3,77 & 3,90 & 3,65 & 3,65 \\
\hline \multicolumn{6}{|c|}{ Кількість поросят при відлучені, гол } \\
\hline $\mathrm{QBB} \times \widehat{\mathrm{O} B \bar{L}}$ & 12,1 & & & & \\
\hline क्र× & 11,9 & & & & \\
\hline कВБ $\times \partial^{\lambda} \Omega$ & 12,3 & 2,50 & 1,65 & 1,65 & 3,36 \\
\hline 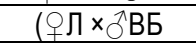 & 12,8 & 6,67 & 7,56 & 5,79 & 5,79 \\
\hline \multicolumn{6}{|c|}{ Маса одного поросяти при відлученні, кг } \\
\hline 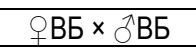 & 6,66 & & & & \\
\hline $9 \Omega \times \partial^{\lambda} \Omega$ & 6,75 & & & & \\
\hline$q \mathrm{~B} B \times \widehat{\partial} Л$ & 6,72 & 0,22 & 0,90 & $-0,44$ & $-0,44$ \\
\hline$($ ( & 6,69 & $-0,22$ & $-0,89$ & $-0,89$ & 0,45 \\
\hline \multicolumn{6}{|c|}{ Маса гнізда поросят при відлучені, кг } \\
\hline 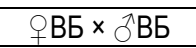 & 80,6 & & & & \\
\hline क्र & 80,3 & & & & \\
\hline कВБ $\times \delta^{\wedge} Л$ & 82,7 & 2,80 & 2,61 & 2,61 & 2,99 \\
\hline$\left(9 \Omega \times O^{\wedge} \mathrm{BL}\right.$ & 85,6 & 6,40 & 6,60 & 6,20 & 6,20 \\
\hline \multicolumn{6}{|c|}{ Середньодобовий приріст поросят сисунів, г } \\
\hline $\mathrm{OB} \times \mathrm{O} \mathrm{B} B$ & 198 & & & & \\
\hline 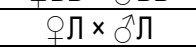 & 201 & & & & \\
\hline $9 \mathrm{~B} E \times \mathrm{O}^{\lambda} Л$ & 201 & 0,75 & 1,52 & 0,00 & 0,00 \\
\hline$\left(\Phi \Omega \times O^{\lambda} \mathrm{B} B\right.$ & 199 & $-0,25$ & $-1,00$ & $-1,00$ & 0,51 \\
\hline
\end{tabular}

Маса гнізда поросят при відлучені залежить від кількості поросят в ньому на цей час та їх індивідуальної маси. Вищим ефект гетерозису за цією ознакою виявився в гніздах поросят у свиноматок породи ландрас осімененних спермою кнурів великої білої породи. Найвищим значенням характеризувався загальний гетерозис як переважання помісей над материнською формою - 6,60\%, тоді як гіпотетичний, який характеризує переважання помісей над середнім значенням обох вихідних форм склав 6,40\%. Водночас справжня та специфічна форми гетерозису за масою гнізда при відлучені знаходились за даного поєднання материнських генотипів на рівні 6,20\%.

На інтенсивність росту поросят в підсисний період здійснюють вплив як генетичний потенціал росту визначений спадковістю матері та батька, так і пратипові фактори умов утримання, захисту їх здоров'я, терміни початку підгодівлі поросят та якість престартерних кормів, рівень годівлі свиноматок та інше. За цією ознакою, як при прямому так і при зворотному схрещуванні ефект гетерозису був низьким, або зовсім відсутнім. Так при схрещуванні свиноматок великої білої породи з кнурами породи ландрас встановлено тільки загальний гетерозис на досить низькому рівні - 1,52\% та гіпотетичний на рівні 0,75\%. Решта фрорм гетерозису була відсутня.

За зворотного варіанту поєднання тварин цих порід спостерігався незначний ефект специфічного гетерозису за середньодобовими приростами в підсисний період на рівні $0,51 \%$. Решта фрорм гетерозису мала негативне значення від 0,25 до $1,00 \%$.

Ефект гібридної сили за комплексом ознак відтворювальних якостей свиноматок за різних варіантів їх схрещування вивчали шляхом розрахунків селекційного індексу відтворювальних якостей (СІВЯС) та оціночним індексом 3 обмеженою кількістю ознак (IBЯ). За показником СІВЯС найвищим був ефект специфрічного гетерозису за поєднання порід ОВБ $\times$ § Л -8,88\%, тоді як гіпотетичний гетерозис за СІВЯС склав 8,26\%, а загальна та справжня його форми знаходились на рівні 7,65\% (табл. 3).

Таблиця 3

\section{Ефект гетерозису за комплексом показників відтворювальної якості}

\begin{tabular}{|c|c|c|c|c|c|}
\hline Поєднання порід & Показник & Гіпотетичний гетерозис, \% & Загальний гетерозис, \% & Справжній гетерозис, \% & Специфічний гетерозис, \% \\
\hline \multicolumn{6}{|c|}{ СВІЯС, балів } \\
\hline 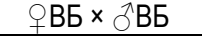 & 115,1 & & & & \\
\hline क्र× & 113,8 & & & & \\
\hline कВБ $\times \hat{~} \sigma^{\top} Л$ & 123,9 & 8,26 & 7,65 & 7,65 & 8,88 \\
\hline$($ ( & 116,8 & 2,05 & 2,64 & 1,48 & 1,48 \\
\hline \multicolumn{6}{|c|}{ Оцінюючий індекс відтворювальних якостей IBЯ, балів } \\
\hline 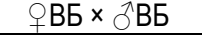 & 45,8 & & & & \\
\hline क्र× & 45,3 & & & & \\
\hline 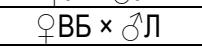 & 47,4 & 4,06 & 3,49 & 3,49 & 4,64 \\
\hline$\left(9 \Omega \times{ }^{\wedge} \mathrm{B} Б\right.$ & 47,6 & 4,50 & 5,08 & 3,93 & 3,93 \\
\hline
\end{tabular}

За поєднання свиноматок породи ландрас з кнурами великої білої породи ефекти гетерозису за СІВЯС виявилися нижчими. Так загальний гетерозис за комплексом цих ознак склав для даного поєднання 2,64\%, гіпотетичний $-2,05 \%$, а 
специфічний та справжній по 1,48\%.

Гетерозисний ефект за комплексом ознак включених в IBЯ мав дещо інші значення. Так за прямого схрещування маток великої білої породи з плідниками породи ландрас різні форми гетерозису знаходились на рівні 3,49-4,64\%, тоді як за зворотного варіанту поєднання цих порід він був дещо вищим і становив 3,93-5,08\%. За прямого схрещування найвищим показником характеризувалась специфічна форма гетерозису, тоді як за зворотного - загальна його форма.

Висновки. 1. За більшістю відтворювальних якостей свиноматок материнських генотипів великої білої та ландрас порід виявлено есрект гетерозису як при прямому так і зво- ротному їх схрещуванні.

2. При схрещуванні свиноматок великої білої породи з кнурам породи ландрас найвищим прояв ефректу гетерозису був за загальною кількістю поросят при народжені $1,18 \ldots 8,86 \%$, багатоплідності - 7,48 ... 8,97\% та селекційним індексом відтворювальних якостей (СІВЯС) - 7,85$8,88 \%$

3. За реципрокного варіанту схрещування тварин цих порід найвищим показник гетерозису виявився за кількістю поросят при відлучені - 5,79 .. 7,56\%, масою поросят при відлучені 6,20 ... 6,60\% та оціночним індексом з обмеженою кількістю ознак (IBЯ) - 3,93 ... 5,08\%.

\section{Список використаної літератури:}

1. Анкер А. Задачи и проблемы селекции и гибридизации свиней. Актуальные вопросы прикладной генетики в животноводстве. М.: Колос, 1982,С. 216-252

2. Березовский Н. Д. Методика моделирования индексов для использования их в селекции свиней. Методы улучшения процессов селекции, разведения и воспроизводства свиней (методические указания). М., 1986. С. 3-14

3. Ващенко П.А. Комбінаційна здатність заводських ліній свиней великої білої породи. Вісник Полтавської державної аграрної академії. 2009. № 3. С. 71-73

4. Гетя А.А. Організація селекційного прогресу в сучасному свинарстві: Монографбія. Полтава: Полтавський літератор, 2009. c.192 104-106

5. Горин И.Т., Никитченко И.Н. Возможность прогнозирования гетерозиса у свиней. Труды БелНИИЖ. 1969. Т. 10. С.

6. Гришина Л.П. Методологія створення спеціалізованого типу свиней: Монографрія. Полтава: ТОВ «Фірма «ТехсерBic. 2015. c. 236

7. Грудев Д.И. Зоотехнические аспекты крупноплодности свиней. Свиноводство. 1976. № 11. С. 25-27

8. Жирнов Ф.В. Межлинейная гибридизация в свиноводстве. М.: Колос, 1980. с. 87

9. Зиновьева Н.А., Гладырь Е.А., Ларионова П.В., Калачакова О.В., Лобан Н.А. Исследование полиморфизма гена эстрагенового рецептора - как маркера плодовитости свиней. Материалы междунар.научно-практич. конфр. «Прошлое, настоящее и будущее зоотехнической науки». Дубровицы, 2004. С. 50-57

10. Лісний В. А. Підвищення ефективності гетерозисної селекції в свинарстві шляхом оцінки комбінаційної здатності порід та типів свиней. Вісник аграрної науки Причорномор'я. Миколаїв, 2002. Вип. 3 (17). С. 58-67

11. Михалко О.Г., Повод М.Г. Відтворювальні якості свиноматок данського та французького походження в умовах промислового комплексу. Вісник Сумського національного аграрного університету. Серія "Тваринництво". Випуск 1-2 (3637), 2019. C. $15-26$

12. Піотрович Н.А. Формування відтворювальних якостей свиноматок та оцінка їх комбінаційної здатності. Авторефр. дис. канд. с.-е. наук: 06.02 .01 «Розведення та селекція тварин». Миколаїв, 2017. с. 19

13. Повод Н.Г., Михалко А.Г. Интенсивность роста поросят и сезонная продуктивность свиноматок фрранцузского и датского происхождения. Сб. науч. ст. «Зоотехническая наука Беларуси». Жодино, 2020, Том 55, Часть 1. С. 156-171

14. Рыбалко В.П., Гетя А.А. Состояние, перспективы и научное обеспечение отрасли свиноводства. Таврійський науковий вісник. 2008. Вип. 52/2. С. 3-9.

15. Храмкова О.М. Відтворювальні якості свиноматок за різних поєднань порід і типів. Theoretical and Applied Veterinary Medicine, 7(2), 2019 115-119. doi: 10.32819/2019.71021

16. Церенюк О.М. Методологія визначення ефекту гетерозису в свинарстві. Науково-технічний бюлетень, 2018. Вип. 119. C. $173-184$

17. Церенюк О.М. Об'єктивна оцінка материнської продуктивності свиней. Таврійський науковий вісник. 2010. Вип. 78, Ч. 2(I). C. $221-227$

18. Шейко Р.И. Приемы и методы в селекции свиней, обеспечивающие высокий эфффект гетерозиса в системах гибридизации. Монографиия. Жодино, 2012. 263 с. 4-23

19. Шульга Ю.І. Продуктивні якості та комбінаційна здатність лінії Бериславця 4465 при різних формах підбору. Автореф. дис. на здобуття наук. ступеня канд. с.-2. наук: спец. 06.02.01 "Розведення та селекція тварин". Херсон, 2003. с. 18

20. Avalos, E., Smith, C. 1985. Selecting for litter size. Pig Fafrming. Vol. 38, issue 12. pp. 65-88

21. Huang, Y.H., Lee, Y.P., Yang, T.S. and Roan S.W., 2003. Effects of Sire Breed on the Subsequent Reproductive Performances of Landrace Sows. Asian Australasian Journal of Animal Sciences, issue 16(4), p. 7, DOI: 10.5713/ajas.2003.489.

22. Knecht, D., Srodon, S. and Duziński, K., 2015. Breed on selected reproductive performance parameters of sows. Arch. Anim. Breed, issue 58, pp. 49-56. 


\section{References:}

1. Anker, A., 1982. Zadachi i problemyi selektsii i gibridizatsii sviney. Aktualnyie voprosyi prikladnoy genetiki v zhivotnovodstve [Tasks and problems of selection and hybridization of pigs. Current issues of applied genetics in animal husbandry]. M.: Kolos, pp. 216-252

2. Berezovskiy, N.D., Pochernyaev, F.K. and Korotkov, V.A., 1986. Metodika modelirovaniya indeksov dlya ispolzovaniya in v selektsii sviney [Methodology for modeling indices for use in breeding pigs]. Metodyi uluchsheniya protsessov selektsii, razvedeniya i vosproizvodstva sviney (metodicheskie ukazaniya), pp. 3-14.

3. Vashchenko, P.A., 2009. Kombinatsiina zdatnist zavodskykh linii svynei velykoi biloi porody [Combination ability of factory lines of pigs of big white breed]. Visnyk Poltavskoi derzhavnoi ahrarnoi akademii, issue 3, pp. 71-73

4. Hetia, A.A., 2009. Orhanizatsiia selektsiinoho prohresu v suchasnomu svynarstvi [Organization of selection progress in modern pig breeding]. Abstract of Ph.D. dissertation. Poltava: Poltavskyi literator

5. Gorin, I.T. and Nikitchenko, I.N., 1969. Vozmozhnost prognozirovaniya geterozisa u sviney [Ability to predict heterosis in pigs]. Trudyi BelNIIZh, issue 10, pp. 104-106

6. Hryshyna, L.P., 2015. Metodolohiia stvorennia spetsializovanoho typu svynei [Methodology of creating a specialized type of pigs]. Monograph, Poltava. TOV «Firma «Tekhservis, p. 236.

7. Grudev, D.I., 1976. Zootehnicheskie aspektyi krupnoplodnosti sviney[ Zootechnical aspects of pig fertility]. Svinovodstvo, issue11, pp. 25-27 los, p. 87

8. Zhirnov, F.V., 1980. Mezhlineynaya gibridizatsiya v svinovodstve [Interlinear hybridization in pig breeding]. Moscow. Ko-

9. Zinoveva, N.A., Gladyir, E.A., Larionova, P.V., Kalachakova, O.V. and Loban N.A., 2004. Issledovanie polimorfizma gena estragenovogo retseptora - kak markera plodovitosti sviney [Study of estrogen receptor gene polymorphism as a marker of pig fertility]. Materialyi mezhdunar.nauchno-praktich. konf. «Proshloe, nastoyaschee i buduschee zootehnicheskoy nauki». Dubrovitsyi, pp. 50-57.

10. Lisnyi, V. A., 2002. Pidvyshchennia efektyvnosti heterozysnoi selektsii v svynarstvi shliakhom otsinky kombinatsiinoi zdatnosti porid ta typiv svynei [Improving the efficiency of heterosis selection in pig breeding by assessing the combination ability of breeds and types of pigs]. Visnyk ahrarnoi nauky Prychornomoria. Mykolaiv, issue 3 (17), pp. 58-67.

11. Mykhalko, O.H., Povod, M.H., 2019. Vidtvoriuvalni yakosti svynomatok danskoho ta frantsuzkoho pokhodzhennia v umovakh promyslovoho kompleksu [Reproductive qualities of sows of Danish and French origin in the conditions of an industrial complex]. Visnyk Sumskoho natsionalnoho ahrarnoho universytetu. Seriia «Tvarynnytstvo», issue 1-2 (36-37), pp. 15-26.

12. Piotrovych, N.A., 2017. Formuvannia vidtvoriuvalnykh yakostei svynomatok ta otsinka yikh kombinatsiinoi zdatnosti $x$ Formation of reproductive qualities of sows and evaluation of their combination abilityï. Dissertation abstract. Mykolaiv

13. Povod, M.H, Mykhalko, O.H., 2020. Intensivnost rosta porosyat i sezonnaya produktivnost svinomatok frantsuzskogo datskogo proishozhdeniya [Growth intensity of piglets and seasonal productivity of sows of French and Danish origin]. Sb. nauch. st. «Zootehnicheskaya nauka Belarusi». Zhodino, issue 55, Vol. 1, pp. 156-171

14. Ryibalko, V.P., Getya, A.A., 2008. Sostoyanie, perspektivyi i nauchnoe obespechenie otrasli svinovodstva [State, prospects and scientific support of the pig industry]. Tavriyskiy naukoviy visnik, issue 52/2, pp. 3-9.

15. Khramkova, O.M., 2019. Vidtvoriuvalni yakosti svynomatok za riznykh poiednan porid i typiv [Reproductive qualities of sows in different combinations of breeds and types]. Theoretical and Applied Veterinary Medicine, issue 7(2), pp. 115-119. doi: 10.32819/2019.71021

16. Tsereniuk, O.M., 2018. Metodolohiia vyznachennia efektu heterozysu v svynarstvi [Methodology for determining the effect of heterosis in pig breeding]. Naukovo-tekhnichnyi biuleten, issue 119, pp. 173-184.

17. Tsereniuk, O.M., 2010. Obiektyvna otsinka materynskoi produktyvnosti svynei [Objective assessment of maternal productivity of pigs]. Tavriiskyi naukovyi visnyk. Issue 78, Vol. 2(I), pp. 221-227

18. Sheyko, R.I., 2012. Priemyi i metodyi v selektsii sviney, obespechivayuschie vyisokiy effekt geterozisa v sistemah gibridizatsii [Techniques and methods in pig breeding that provide a high effect of heterosis in hybridization systems]. Monograph, Zhodino, pp. 4-23

19. Shulha Yu.I. Produktyvni yakosti ta kombinatsiina zdatnist linii Beryslavtsia 4465 pry riznykh formakh pidboru [Productive qualities and combination ability of the Berislavets 4465 line at various forms of selection]. Dissertation abstract. Kherson

20. Avalos, E., Smith, C. 1985. Selecting for litter size. Pig Fafrming. Vol. 38, issue 12. pp. 65-88

21. Huang, Y.H., Lee, Y.P., Yang, T.S. and Roan S.W., 2003. Effects of Sire Breed on the Subsequent Reproductive Performances of Landrace Sows. Asian Australasian Journal of Animal Sciences, issue 16 (4), p. 7, DOI: 10.5713/ajas.2003.489.

22. Knecht, D., Srodon, S. and Duziński, K., 2015. Breed on selected reproductive performance parameters of sows. Arch. Anim. Breed, issue 58, pp. 49-56.

\footnotetext{
Ukraine)

Povod Mykola Hryhorovych, Doctor of Agricultural Sciences, Professor, Sumy National Agrarian University (Sumy,

Tsap Svitlana Volodymyrivna, PhD in Agricultural Sciences, Associate Professor, Dnipro state agrarian and economic university (Dnipro, Ukraine)
}

Ohloblia Viktoriia Viktorivna, candidate for higher education Doctor of Philosophy, Poltava State Agrarian Academy (Poltava, Ukraine) 


\section{of Ukraine}

Manifestation of the combination ability of pigs of Irish selection in the industrial production of pork in the steppe

The article evaluates the effect of heterosis for direct and reciprocal formation of the main material rocks of large white and landrace of Irish origin in terms of industrial technology of pork production in the steppe of Ukraine. The study revealed the manifestation of the effect of heterosis on most maternal traits in both direct and reverse crossing of the main maternal breeds. But on different grounds, its effect was different. The effect of heterosis in both direct and reverse crossing has been established in terms of fertility. The highest in direct crossing was the specific heterosis - 8,97\%, while the true and total heterosis were at 7,48\%. In the reverse variant of the combination of pigs of these breeds, the total heterosis in terms of fertility was $3,45 \%$, the true and specific heterosis was 2,04\%, while the hypothetical was 2,74\%. In sows of large white breed when combined with boars of Landrace breed, negative values of all types of heterosis were observed at the level of 5,24 -5,47\%. In the reverse combination of pigs of these breeds, a positive total heterosis was found $-3,90 \%$, true and specific was $3.65 \%$, and hypothetical $-3,77 \%$. In terms of the number

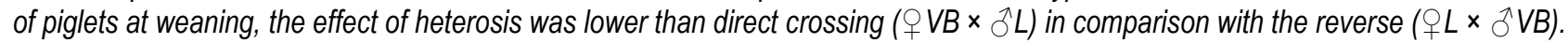
Thus, in direct crossing, the specific heterosis was 3,36\%, while the hypothetical 2,50\%. For backcrossing of animals of these breeds, the effect of total heterosis was 7,56\%, true and specific heterosis 5,79\% and hypothetical $-6,67 \%$. The effect of heterosis on the nest weight of piglets when weaned in sows of Landrace breed inseminated with sperm boars of large white breed was as follows - general - 6,60\%, hypothetical - 6,40\%, true and specific - 6,20\%. The effect of hybrid force on the complex of traits of reproductive qualities of sows on the indicator SIVYAS was the highest effect of specific heterosis for the combination of breeds O VB $\times \widehat{O}^{2} \mathrm{~L}-8,88 \%$, while the hypothetical heterosis on SIVYAS was 8,26\%, and the general and true forms were at the level of $7,65 \%$. When combining Landrace sows with large white boars, the effects of heterosis on SIVYAS total heterosis on the complex of these traits for this combination was $2.64 \%$, hypothetical $-2,05 \%$, and specific and true $1,48 \%$. According to the majority of reproductive qualities of sows of maternal genotypes of large white and landrace breeds, the effect of heterosis was revealed both at their direct and reverse crossing. When crossing sows of large white breed with boars of Landrace breed, the highest manifestation of the effect of heterosis was on the total number of piglets at birth $-1,18 \ldots 8,86 \%$, fertility $-7,48 \ldots 8,97 \%$ and selection index of reproductive qualities (SIVYAS) - 7,85-8,88\%. In the reciprocal variant of crossing animals of these breeds, the highest rate of heterosis was found in the number of piglets at weaning $-5,79 \ldots 7,56 \%$, the weight of piglets at weaning $6,20 \ldots 6,60 \%$ and the estimated index with a limited number of traits (IVA) - 3,93... 5,08\%.

Key words: sow, breed, combination, heterosis, fertility, crossing, average daily gains

Дата надходження до редакції: 16.12.2020 p. 